\title{
7 \\ The (Immediate) Post-World War II Period
}

\author{
Antonello Tancredi
}

\section{Setting the Scene}

What Lucretius said about nature is also true of juridical experience, namely that non facit saltus. The interwar period essentially transmitted to the subsequent Italian doctrine two scientific orientations as its legacy. ${ }^{1}$ On the one hand was Perassi's dogmatism of normativist origin, also adopted by Anzilotti in 1928, ${ }^{2}$ when the latter author abandoned the voluntarist positivism hinged on the idea of "collective will" as the sole basis upon which the juridical character of international law rested, and embraced the thesis of the fundamental norm. ${ }^{3}$ On the other hand was the structuralism inaugurated by the institutionalist theory of Santi Romano, who had sought to break away from the obsession with normogenesis (the derivation of a norm from another norm, to reach a presupposed basic norm) and bring the juridical phenomenon back to its social basis (ubi societas ibi ius), what he called the "institution": ${ }^{4}$ given that the international community is organized, in the sense that it has a stable and permanent structure, this implies that it translates itself into an autonomous legal order, 5

Naturally, behind both of these orientations were various influences and derivations-Triepel's Gemeinwille (collective will) and Vereinbarung (normative agreement) originally affected Anzilotti; Kelsen's hierarchical structure (Stufenbautheorie) and the idea of the legal norm as a hypothetical judgment and not a command guided Perassi; and Hauriou and Duguit influenced Romano, although the Italian version of their theories never coincided with the original. According to Anzilotti (and in contrast to Triepel, for instance), the international legal order constituted a unity and not a juxtaposition of normative agreements; Perassi, in homage to the traditional dualism of Italian doctrine, did not follow Kelsenian monism; and Santi Romano never accentuated the idea of

1 See Enrique Pecourt Garcia, Tendencias actuales de la doctrina italiana de derecho internacional publico (Valencia: Institucion Alfonso El Magnanimo, 1965), 104. See, furthermore, in this volume Chapter 6 by Giulio Bartolini.

2 Dionisio Anzilotti, Corso di diritto internazionale (3rd ed, Roma: Athenaeum 1928), $42 \mathrm{ff}$.

3 Ibid., 45.

4 Santi Romano, Lordinamento giuridico (Pisa: Spoerri 1918); Santi Romano, Corso di diritto internazionale (Padova: Cedam1926), 5-6.

5 Romano, Corso di diritto internazionale, 6. 
social necessity or solidarity that played a pivotal role in the cited French authors' reconstructions.

Furthermore, the two currents of thought mentioned above were not without reciprocal influences: these multiplied when, after World War II, other authors developed, updated, and innovated their doctrinal orientations. In this regard, the clearest example of the eclecticism that, in some cases, characterized Italian doctrine in the early years of the post-World War $\mathrm{II}^{6}$ period is probably the theory of "spontaneous law", especially in Ago's version. This theory, in fact, was influenced both by Santi Romano's rejection of custom as a tacit agreement and his emphasis on the factual element of spontaneous law, ${ }^{7}$ and by Perassi's idea of the norm as an evaluative canon and not a command. ${ }^{8}$ Ago then proceeded to mix elements of natural law (the conscience of the associates as the "seat" of spontaneous law) 9 with some aspects of imperativism (a rule has a legal nature because it is "guaranteed"). ${ }^{10}$ Another case in point is Quadri's "realism", which has been defined ${ }^{11}$ as an attempt to reconcile the imperativism of traditional positivism-according to which law is a command posited by a superior authority that is capable of imposing sanctions in the event of transgression - with the sociologism of the institutionalist theory, since such authority is neither a super-State nor a fundamental norm, but the international community personified by States acting uti universi (and not uti singuli). In short, law is a product of social reality, as also maintained by Giuliano.

In addition to a tendency toward eclecticism, another characteristic feature of the Italian internationalist doctrine after World War II was its enduring adherence to the positive method, namely the idea that legal science must reject any intrusion of ideologies and meta-empirical values in its investigations (even if the jusnaturalist tradition continued to be represented by increasingly isolated voices), ${ }^{12}$ and, on the other hand, that this science must stick to empirical experience in the researching of legal rules (i.e. must analyze law as it is, not as it should be, therefore respecting a rigorous differentiation between lex lata and lex ferenda). Adherence to this method was also assured by the authors who had been actively engaged as partisans in the anti-Nazi resistance (Migliazza, Giuliano, Ziccardi, Barile), and whose scientific works do not reveal clear or immediately apparent traces of their

6 Massimo Panebianco, 'Tradition und neue Tendenzen in der italienischen Völkerrechtslehre nach 1945', 25 Archiv des Völkerrechts (1987), 387, 389, speaks of 'eklektische Schule'.

7 Francesco Salerno, 'L'influenza di Santi Romano sulla dottrina e la prassi italiana di diritto internazionale', 101 RDI (2018) 357, 372-3.

8 Francesco Salerno, 'Laffermazione del positivismo giuridico nella scuola internazionalista italiana: il ruolo di Anzilotti e Perassi', 95 RDI (2012) 29, 52.

9 Panebianco (n. 6), 390, defines spontaneous law as "Neunaturrechtslehre".

10 Roberto Ago, 'Science juridique et droit international', 90 RCADI (1956-II), 857, 926-8.

11 Carlo Focarelli, Introduzione storica al diritto internazionale (Milano: Giuffré 2012), 471-3.

12 See, for instance, Gabriele Salvioli 'La règle de droit international', 73 RCADI (1948-II) 373. See also Giorgio Balladore Pallieri, Diritto internazionale pubblico (7th ed, Giuffrè 1956), 31, who places the ultimate foundation of law in a higher moral norm. 
political ideas. ${ }^{13}$ However, this does not mean that such traces are completely absent, as demonstrated, for example, by Giuliano's work, based on the idea of law as a product, or a superstructure, of society, and as such influenced by historical materialism.

Finally, a third characteristic that can be ascribed to Italian internationalist doctrine, especially in the late 1940s and early 1950s, was the tendency toward formalism and conceptualism. ${ }^{14}$ Despite the intentions of the positive method, in those years theoretical, logical and technical, and sometimes abstract reasoning still largely prevailed over attention to international practice and to real problems. The most significant writings of this period focused-as will be analyzed subsequently - on the legal foundation and the social basis of international law, and were characterized by some typical virtues of the Italian scholarship (theoretical reasoning, acquaintance with the literature in all languages, a clear distinction between law and politics ... and also a certain vis polemica), although they have nonetheless not escaped the criticisms of 'pure theorizing', or 'hyper-refined abstract theory. ${ }^{\prime}{ }^{15}$ On the other hand, several commentators have emphasized that strict adherence to the positive method, formal abstraction, and conceptualismwhile sometimes distancing the doctrine from practical life-constituted a legacy of the fascist period, during which resorting to technicalities protected the Italian scholarship from the pressure of the fascist regime. ${ }^{16}$ The habit of investigating the juridical phenomenon in its theoretical dimension only began to decline in the late 1950s (in this regard, a case in point is Giuliano's monograph of 1956, I diritti e gli obblighi degli Stati) ${ }^{17}$ and more decisively from the mid-1960s.

Finally, some clarifications are in order before continuing. The editorial limits of this work impose choices, and our choice was to focus on the main doctrinal trends of the immediate post-war period, due to both their scientific relevance and 'the battle of theories' ${ }^{18}$ on the foundation and structure of the international legal order that took place between the end of the 1940s and the beginning of the 1950s, resulting in significant and enduring contributions to the scholarly debate. In short, rather than making a broad but necessarily very brief overview of the post-World

13 Antonio Cassese, 'Diritto internazionale', in Luigi Bonanate (ed), Studi internazionali (Torino: Edizioni della Fondazione Giovanni Agnelli 1990), 118-19.

${ }^{14}$ Enzo Cannizzaro, 'La doctrine italienne et le développement du droit international dans l'aprèsguerre: entre continuité et discontinuité, 50 AFDI (2004), 1, 4.

${ }^{15}$ Josef Kunz, 'Review to La Fonte Suprema dellordinamento internazionale by Giuseppe Sperduti', 42 AJIL (1948), 241, 242.

16 Angelo Piero Sereni, The Italian Conception of International Law (New York: Columbia University Press 1943), 277.

17 Mario Giuliano, I diritti e gli obblighi degli Stati. Lambiente dellattività degli Stati (Padova: Cedam 1956), vol. I. As pointed out by Francesco Capotorti, 'La dottrina italiana di diritto internazionale pubblico nel 1956', 9 Comunicazioni e studi (1957), 255, 288, one of the greatest merits of this monograph was the fact that it was 'entirely built on the data of international reality', a method that conferred it true and concrete originality.

18 Giuseppe Barile, 'Recenti tendenze della dottrina italiana di diritto internazionale pubblico (19521953)', 5 Comunicazioni e studi (1953), 467, 469. 
War II doctrine, we prefer to foster an encounter between the reader and some great scientific personalities of the Italian international law scholarship. This selection, obviously, cannot but reflect the opinions (and limitations) of the author.

\section{The Legal Foundation of International Law: Dogmatism and its Developments (Morelli, Ziccardi, and Sperduti)}

As already hinted at, one of the most recurrent topics analyzed by the Italian scholarship in the aftermath of World War II was the foundation of the legal character of international law. This topic should not be considered only in its abstractness, since it is closely linked to the theory of sources. In fact, one of the central aspects that favored the emergence of the new post-war theories was the vindicatio in libertatem of custom, generally no longer qualified as a tacit agreement. Interest in this subject was, furthermore, not only nurtured by the necessity to update and revise the writings already devoted to it prior to World War II by the members of the two currents of thought mentioned above (dogmatism and structuralism). Indeed, according to Cassese, ${ }^{19}$ the scholarly focus on the legal basis of the international legal order was also a consequence of the fact that the war had shown how dramatically States could seriously violate international law. Hence the need to tackle anew the problem of the validity or the mandatory nature of international norms, seeking (through a positive method) an answer within the law, rather than in other social sciences.

Within the dogmatic orientation, that which shows greatest continuity with Perassi's theory is probably Morelli's analysis, as expressed in his influential textbook published in seven editions between 1943 and 1967 and reiterated in his general course at The Hague Academy. ${ }^{20}$ As already mentioned, Perassi's dogmatism constituted an autonomous reworking of some Kelsenian ideas, in particular the hierarchical construction of the juridical order, on the top of which (first) Perassi placed the pacta sunt servanda rule. ${ }^{21}$ This was considered to be the only general norm on legal production capable of guaranteeing the unity of the international legal order. Moreover, it was the only "basic norm" compatible with the parity structure of the international community. As in the Kelsenian tradition, this general norm was a postulate. Later on, Perassi abandoned the theory of the basic norm to embrace the idea of a group of fundamental norms, whose formation can only be explained historically, but whose legality remains a postulate. ${ }^{22}$

19 Cassese (n. 13), 120.

20 Gaetano Morelli, Nozioni di diritto internazionale (7th ed, Padova: Cedam 1967), 8-10; Gaetano Morelli, 'Cours général de droit international public', 89 RCADI (1956-I), 441, 448-9.

21 Tomaso Perassi, 'Teoria dommatica delle fonti di norme giuridiche in diritto internazionale', 12 RDI (1917), 195.

22 Tomaso Perassi, Lezioni di diritto internazionale (Roma: Anonima romana editoriale 1933), 35. 
Gaetano Morelli (1900-89, full professor in Naples and Rome, editor-inchief of the Rivista di diritto internazionale when it resumed publication in 1953 and then judge at the ICJ), adopts a hierarchical construction concluding with a fundamental rule of legal production (basic norm). This rule, as in Perassi, is presupposed, that is to say it constitutes a postulate that cannot be proved on a juridical level. The soundness of this postulate is provided solely by its suitability to explain reality logically. Unlike Perassi and Anzilotti, however, Morelli maintains that this basic norm does not correspond to the pacta sunt servanda principle. Indeed, according to Morelli (although the idea had already been advocated by Santi Romano), ${ }^{23}$ custom does not have its basis in voluntarism, and therefore cannot be characterized as a tacit agreement. Moreover, the fundamental rule must be unique, that is, it must justify the juridical nature of both agreements and customs, otherwise one would have two international legal systems. However, since the pacta sunt servanda principle, which contemplates agreements as a normative source, has a customary nature, one can conclude that the basic and unique rule which explains the legal nature of both agreements and customs is that which confers on custom the ability to create, modify, and extinguish legal situations, namely the principle consuetudo est servanda.

In contrast, the monographs published by Ziccardi in $1943^{24}$ and Sperduti in $1946^{25}$ are less consistent with the traditional dogmatic approach. The main novelty common to both of these works consists in their signaling the need for a pre-dogmatic phase. They propose moving beyond the "exclusive" constructivist scheme typical of early normativism. In other words, for both these authors the nomogenetic question is only one aspect of the problem of the foundation of international law. It must be preceded by a pre-dogmatic moment in which the juridical science should discover, and not deduce, the fundamental norms that lie the origin of the system. Their affirmation of the necessary coexistence of the inductive and deductive methods of inquiry marks a methodological novelty that will subsequently be taken up by several other authors, and constitutes a sort of bridge with the structuralist doctrine (Quadri and Giuliano), as well as with Ago. The limit to these two reconstructions, however, is that they stop halfway in addressing the weak points of normativism, and try to identify a basic norm, or a highest source, as the foundation of the international legal order.

According to Ziccardi, the basic norm is a true positive norm and cannot be presupposed. ${ }^{26}$ This would destroy the autonomy of the science of law, which would constitute an appendix of other sciences. ${ }^{27}$ To determine the constitutional norms

23 See the entry 'Diritto e morale', in Santi Romano (ed), Frammenti di un dizionario giuridico (Milano: Giuffrè 1947), 66.

24 Piero Ziccardi, La Costituzione dell'ordinamento internazionale (Milano: Giuffrè 1943).

25 Giuseppe Sperduti, La Fonte Suprema dell'ordinamento internazionale (Milano: Giuffrè 1946).

26 Ziccardi (n. 24), 46 ff.

27 Ibid., 88-9. 
of the international legal order (i.e. the order's highest norms), and among them the basic norm, which is the highest of the constitutional norms and the supreme norm on sources, ${ }^{28}$ one must look at the data offered by empirical experience using an inductive method (and this is the most innovative aspect of his theory). ${ }^{29}$ The science of law is a science of juridical experience. Once inductive investigation has identified fundamental norms, it is subsequently possible to resort to deductive investigation to derive other norms. ${ }^{30}$ Custom is the highest source of international law, ${ }^{31}$ and this is only natural because it fits with the parity structure of this legal order and its high degree of decentralization. ${ }^{32}$

According to Sperduti, on the other hand, the highest source is constituted by a pre-legal custom based on the idea of social dutifulness (doverosità sociale). ${ }^{33}$ This pre-juridical custom constitutes the process via which the international community organizes itself. The highest source is, therefore, the normative fact of effective self-organization. Sperduti thus echoes the later version of Perassi, when he places at the top of the legal hierarchy a set of fundamental norms, which, however (in his view), originate from the pre-juridical custom mentioned above, that is, from a factual phenomenon. In the dogmatic current, Sperduti probably marks the maximum point of inclination toward less formalist positions, moving closer to structural positivism.

In short, in Ziccardi and Sperduti the exclusivity of the dogmatic method is overcome by a need to adapt to social reality. In these authors, normativism becomes only a transition between voluntarist positivism (based on the duo "State and law") and structuralism (based on the duo "society and law"), which will be the subject of the next sections.

\section{The Legal Foundation of International Law and Structuralism: Quadri's "Realism"}

Essentially, the novelty brought about by Rolando Quadri (1907-76, full professor in Padova and then mainly in Naples; and the leading spirit behind new legal journals established in the aftermath of World War II, partly in opposition to other "schools" 34 ) is to place the vertical element of social authority within the horizontal structure conceived by Santi Romano, hinged on the concept of the institution

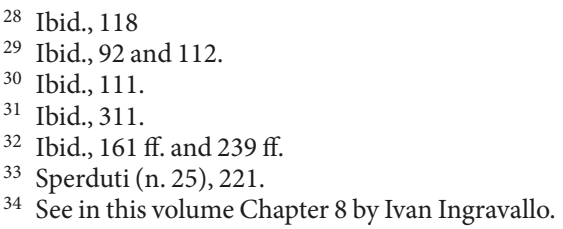


or social body. ${ }^{35}$ In doing this, as mentioned above, Quadri effectively mixed imperativism and institutionalism. The main elements of Quadri's theory, already largely expressed in his textbook originally published in $1949^{36}$ and reiterated in his general course at The Hague Academy, ${ }^{37}$ may be summarized as follows.

Firstly, compared to normativists, Quadri expounds a different ontological conception of law. Legal rules derive their obligatory nature from the fact of being the commands of an authority, that is, because they are posited by those who have the strength to guarantee their execution. ${ }^{38}$ In this sense, according to Quadri, law is authority and social power. ${ }^{39}$ It is always the product of a heteronymous will. ${ }^{40}$ As a consequence, the rule cannot be isolated from the social structure. If detached from this structure, its obligatory nature becomes inexplicable. In the sense ius est factum, law belongs to the empirical reality and not to the world of values.

But how do we apply the phenomenon of authority to an inorganic and decentralized community like the international one? According to Quadri ubi societas ibi auctoritas: in every society there is a power superior to its members (individually considered), which posits and guarantees the rules, ${ }^{41}$ It is true that there is no super-State in the international community that it is not organized institutionally. However, this community does not consist of a mere juxtaposition of States. At the international level, the element of authority must be identified in States operating in the uti universi mode, as active elements in the management of general interests, and not uti singuli, as isolated entities pursuing individual ends, subject to the authority of the law. ${ }^{42}$

Quadri also seeks, in some way, to anticipate the accusation of identifying social authority in the power of the strongest States within the international community, even if he never entirely excludes this possibility. ${ }^{43}$ Indeed, he identifies a "collective will" (although in a sense that differs from Triepel's Gemeinwille), ${ }^{44}$ namely a 'collective psychological phenomenon ${ }^{45}$ consisting in the acceptance by a plurality of States, including even the lesser powers, of the affirmation of a principle as legal. ${ }^{46}$ However, in other passages of his works this author seems, rather, to admit that the will of the social body coincides with the decision of the prevailing forces of

${ }^{35}$ In the post-World War II period, institutionalism found one of its most significant exponents in Riccardo Monaco, Manuale di diritto internazionale pubblico e privato (Torino: UTET 1949). On Monaco's theory, see Pecourt Garcia (n. 1), $134 \mathrm{ff.}$

36 Rolando Quadri, Diritto internazionale pubblico (Palermo: Priulla 1949).

37 Rolando Quadri, 'Cours général de droit international public', 113 RCADI (1964), 237.

38 Rolando Quadri, 'Le fondement du caractère obligatoire du droit international public', 80 RCADI (1952), 583, 620.

39 Rolando Quadri, Diritto internazionale pubblico (5th ed, Napoli: Liguori 1968), 25.

40 Ibid., 36.

41 Ibid., 27.

42 Quadri (n. 38), 624.

43 Quadri (n. 39), 31.

44 Ibid., 35.

45 Ibid., 32.

46 Ibid., 31. 
the international community. According to Quadri, in fact, there are two forms of immediate, direct expression of the will of the social body: the imposition of structural principles or "primary norms", which are not obligatory but effective, and are endowed with a force superior to all other customary and conventional rules; ${ }^{47}$ and intervention, that is, the authoritative interference of one or more States in the internal or international life of another State, to be considered as the primary form of social (and coercive) guarantee of international law. "Principles" are divided into two categories: formal and material. "Formal" principles establish further sources of juridical production and are the principles of pacta sunt servanda and consuetudo est servanda, a solution which implies that custom and treaties are actually secondary norms of the international order. "Material" principles, on the other hand, directly govern social relations, such as the principle of the freedom of the seas. Quadri openly admits that structural principles are based 'on a determination of the prevailing forces of the international community'; ${ }^{49}$ while social intervention is performed by States acting uti universi.

The authoritarian aspect of his theory has earned Quadri widespread criticism, particularly that he ends up legally justifying the abuse of the strongest. ${ }^{50} \mathrm{Or}$, at the very least, that he is incapable of putting forward a normative, non-descriptive theory. On the other hand, Quadri's theory has fascinated generations of jurists due to its originality. Some of the most significant voices of the Italian scientific milieu of the last decades have developed certain intuitions of his, often in an autonomous way, emphasizing the potential of categories, such as the erga omnes obligations, which to some extent formalize Quadri's idea of social guarantee. ${ }^{51}$

Quadri's intuitions and originality were also linked to his eclecticism. This author, in fact, uses concepts that are not entirely novel (social basis or reality, authority, social or collective will), but does so in a way that differs from his predecessors. For example, he acknowledges that the French doctrine (Duguit, Scelle) has the merit of having maintained constant contact between law and social facts, but at the same time he rejects the idea that the foundation of law is the "common good", or social solidarity, or even necessity, despite having actually embraced the "necessity thesis" in his writings, with reference to the "constitutional norms" of general international law. ${ }^{52}$ According to Quadri, in fact, social authority creates and guarantees the law, but is 'often not even inspired by the needs of the common

47 Ibid., 109 and 111.

48 Ibid., 29 and 277.

49 Ibid., 119.

50 See Klaus Lenk, 'Teorie del diritto internazionale pubblico italiano' 3 Politica del diritto (1972) 256; Benedetto Conforti, Appunti delle lezioni di diritto internazionale (Napoli: Editoriale scientifica 1976), 31-3.

${ }^{51}$ See, for instance, the collected works of Paolo Picone, Comunità internazionale e obblighi 'erga omnes' (Napoli: Jovene 2013).

52 Rolando Quadri, 'Stato (diritto internazionale)', in Mariano d'Amelio, Antonio Azara (eds), Nuovo Digesto Italiano (Torino: UTET 1940), vol. XII, 815, 818, reproduced in Rolando Quadri, Studi di dottrina dello Stato (Napoli: Liguori 1964) 77. In our subsequent citations we will refer to this latter text. 
good, ${ }^{53}$ an element which, again, raises the question of legalizing the abuses perpetrated by great powers in defending their individual interests, and not the general interest of the community on behalf of which they act in the uti universi mode. As a consequence, unjust and immoral international norms are certainly possible, as emphasized by positive international law's recognition of slavery. ${ }^{54}$ Similarly, Quadri speaks of "collective" or "social will", but criticizes Triepel's concept of "collective will" as being an 'imaginative expedient, ${ }^{55}$ lacking a basis in reality. Indeed, while Triepel affirms that the collective will detaches itself from the individual wills of States merged in a normative agreement (Vereinbarung), and imposes itself on the contracting States as a superior will, Quadri points out that a will cannot be detached from its originator. The "collective will" of Quadri, in fact, does not depart from its originators' will, but is rather constituted-as already mentionedby a plurality of States' acceptance of the imposition of a principle as legal. The obliging will is always heteronomous. It is not the will to oblige oneself, but to oblige others. And his 'peppercorns ${ }^{56}$ (as Quadri puts it) are also addressed to Kelsen (whose upside-down pyramid, like any inverted pyramid, cannot stand upright, being founded upon a hypothetical basic norm, which renders the whole system hypothetical), and Romano, according to whom international norms cannot derive from an authority superior to the subjects of the community, the latter also not being capable of having a will of its own.

In short, what makes Quadri's theory "realist" is that, in his view, law is the product of the changing and dynamic equilibria that are created between social forces. This element also recurs in the theory of Mario Giuliano, ${ }^{57}$ as explored in the following section.

\section{Mario Giuliano's “Absolute Realism”}

1950 was a critical year, marking the publication of two major works: Roberto Ago's Scienza giuridica e diritto internazionale, and Mario Giuliano's La comunità internazionale e il diritto. For reasons of its greater proximity to Quadri's realism, we shall start by exploring the latter monograph.

The starting point of the analysis conducted by Mario Giuliano (1914-86, full professor in Milan, with a pivotal role in the studies of international law at this leading university, and member of the Chamber of Deputies between 1979 and

53 Quadri (n. 39), 34.

54 Ibid., 37-8.

55 Ibid., 35.

56 Ibid., 7.

57 Mario Giuliano, 'Considerazioni sulla costruzione dellordinamento internazionale', 2 Comunicazioni e studi (1946), 173, 219-20 ('the legal order follows and adapts itself, as a superstructure, to the structural changes and new balances of powers occurring in society'). 
1983 ) is that law is a product, a superstructure, of society (surprisingly, a point already made by Perassi) ${ }^{58}$ A satisfactory construction of the international legal order, therefore, must be built upon the social environment that constitutes the basis of the superstructure. In his view, the unity and autonomy of the international legal order stem from the unity and autonomy of the social environment within which the order operates (an argument that drives Giuliano to embrace dualism). ${ }^{59}$ The norm, as already pointed out by Ago, ${ }^{60}$ is neither a command nor a hypothetical judgment, but a judgment of legal value, ${ }^{61}$ which cannot be determined a priori, as in the hypothetical Kelsenian rule, but only on the basis of an empirical analysis of social reality. ${ }^{62}$

The fault of the pure doctrine of law, therefore, was to impose a drastic detachment of the Sein (is) from the Sollen (ought to be), that is, of reality from law, reaching the conclusion that social reality would be a posterius with respect to the law, while the opposite is actually true. ${ }^{63}$ In this passage we find an argument, also echoed by Quadri, ${ }^{64}$ according to which there is no difficulty in making the transition between Sein and Sollen. This constitutes a fundamental criticism of the Kelsenian principle of the non-deductibility of law from fact (a criticism that-as we shall explore-will be decisive in the development of the idea of the State as a "real" person in international law). Moreover, if customary international norms have their origin in historical facts rather than in other norms, their identification requires the use of an inductive method (the importance of which had already been emphasized by Ziccardi).

If Giuliano first maintains that the juridical character of the norms is the result of the "conviction" of the associates (an element which jeopardized the objective and realistic nature of his thesis, since the legality of norms would become a quality subjectively attributed to them by a certain idea of the members of the social body), ${ }^{65}$ in 1950 the author states that the "reality" or "positivity" of the legal order derives exclusively from the fact that its value judgments are present and operating in the international community "as a whole" ${ }^{66}$ In other words, the source of international legal norms is first of all the community that produces that legal order, as well as the other facts that the community itself considers suitable to produce legal norms. Agreements apart, there is no source of international norms (i.e. of customary norms) other than the spontaneous ${ }^{67}$ formation and existence of

\footnotetext{
58 Mario Giuliano, La comunità internazionale e il diritto (Padova: Cedam 1950), 187 and 221.

59 Giuliano (n. 57), 206.

60 Roberto Ago, 'Le délit international', 68 RCADI (1939-II), 415, 424, footnote 2.

61 Giuliano (n. 58), 187.

62 Ibid., 178 and 180.

63 Ibid., $109 \mathrm{ff}$.

64 Quadri (n. 38), 620-1.

65 Giuliano (n. 57), 186, 201, and 204.

66 Giuliano (n. 58), 224.

${ }^{67}$ Ibid.
} 
common judgments of legal value in the "consciences" of "all" the members of the community in question. ${ }^{68}$ Consequently, unlike Quadri, Giuliano considers that heteronomy and authority are not essential features of law, but rather effects of the perspective adopted by the individual subject, who feels the weight of the authority of the law produced by the community. ${ }^{69}$ Nor is sanction a constitutive element of law (an idea produced by the detachment of law from its social foundation), but rather only one of the many social activities evaluated by it. ${ }^{70}$ The function of law, therefore, is not to create or guarantee a certain social order, but only to reflect a social order already existing in the concreteness of life and history. ${ }^{71}$ However, what remains outside the door of a rejected imperativism in a certain way re-enters through the window of historical materialism, since, as already pointed out, according to Giuliano 'the legal order follows and adapts itself, like a superstructure, to structural changes and to the new balance of forces that occurs in society.72

In his writings, Giuliano expresses an "absolute realism" in contrast to any formalistic abstractness. However, while criticizing Kelsen's and every other apriorism, ${ }^{73}$ he too starts from a postulate ${ }^{74}$ (the Marxist philosophy of historical materialism) ${ }^{75}$ according to which-as pointed out by Kunz-'all law, and not only the "spontaneous" law of Ago, is merely an ideological superstructure of the economic conditions of a certain society at a given time. ${ }^{36}$ Moreover, his affirmation that law is what society considers it to be is tautological. ${ }^{77}$ The risk, once again, is of reducing theory to an empirical description of legal phenomena.

\section{Ago's "Spontaneous Law"}

It is not easy to define the theory of Roberto Ago (1907-95, full professor in Milan and from 1956 in Rome; in charge of multiple initiatives aimed at fostering international law studies in Italy, such as his founding role in the Società italiana per lorganizzazione internazionale and legal journals, in addition to his well-known cursus honorum at the international level). It has sometimes been regarded as neo-naturalist, in particular the idea of "spontaneous" law that has its "seat" in the "conscience" of the members of the international community and cannot but be

${ }^{68}$ Ibid., 187.

${ }^{69}$ Ibid., 188.

70 Ibid., 223.

71 Ibid., 307.

72 Giuliano (n. 57), 219-20.

73 Ibid., 175 and 180 .

74 See, in this sense, Giuseppe Barile, 'Tendenze e sviluppi della recente dottrina italiana di diritto internazionale pubblico (1944-1951)', 4 Comunicazioni e studi (1952), 397, 406.

75 On Mario Giuliano and Marxism see, in this volume, Chapter 10 by Lorenzo Gradoni.

${ }^{76}$ Josef Kunz, 'Roberto Ago's Theory of a "Spontaneous" International Law', 52 AJIL (1958), 85, 85.

77 Barile (n. 74), 407. 
discovered by them. ${ }^{78}$ At other times it has been deemed neo-normativist ${ }^{79}$-due to the normativist positions Ago adopted in his early works, and because he retains the idea that the norm is the only unit of measurement of legal reality. ${ }^{80}$ At yet other times, the presence of elements of imperativism has also been detected, since, in Ago's view, norms are legal also because they are guaranteed, ${ }^{81}$ and this guarantee cannot be but "social" and non-normative. ${ }^{82}$

At a methodological level Ago criticizes the constructivist theory, which reduces the task of legal science to the logical deduction of every single norm from a fundamental premise, however hypothesized or postulated it may be. ${ }^{83}$ Therefore, he also posits that the science of law must base itself on data offered by empirical reality. ${ }^{84}$ Accordingly, like every other science, legal science is fully entitled to use both the inductive and the deductive method. ${ }^{85}$ Based on observation of the data of social reality, he posits that the world of law is a world of judgments and not of commands or hypotheses. ${ }^{86}$ The characteristic of judgments is that they exert an effective influence on the members of the community, since, in the presence of certain factual conditions, they grant or deny them certain subjective legal situations (rights, obligations, etc.). ${ }^{87}$ These judgments (or norms) reside in legal systems characterized by instrumental rules that organize the functions of the production, ascertainment, and guarantee of international norms. ${ }^{88}$

The second point regarding which positivism requires fundamental revision is the dogma that all law must be positive, that is, it must be posited by an act of human will, and must have a "source". According to Ago, apart from positive legal norms, the law "in force" is also composed of norms of "spontaneous germination, ${ }^{89}$ which can logically have no source (only historical, social, rational, or religious causes). ${ }^{90}$ With regard to these norms, legal science only has the task of using an inductive method to discover their existence and operation in the "conscience" (a term also used by Giuliano) of the associates, not of determining their origin. ${ }^{91}$ Ago's reference to the conscience of the members of the social body, however, is

${ }^{78} \mathrm{Kunz}$ (n. 76), 90, for instance, speaks of 'pseudo-natural law construction'. See also Panebianco (n. 6), 390 .

${ }_{79}$ Pecourt Garcia (n. 1), 183.

${ }^{80}$ Ludovico Mattia Bentivoglio, La funzione interpretativa nellordinamento internazionale (Milano: Giuffré 1958), 58.

${ }^{81}$ According to Sereni this would bring Ago back to the imperativist doctrines that he intends to reject. See Angelo Piero Sereni, 'Dottrine italiane di diritto internazionale', in Scritti di diritto internazionale in onore di Tomaso Perassi (Milano: Giuffrè 1957), vol. II, 285.

${ }^{82}$ Quadri (n. 39), 29.

83 Roberto Ago, Scienza giuridica e diritto internazionale (Milano: Giuffrè 1950), 64-5.

${ }^{84}$ Ibid., 64 and 100.

85 Ibid., 66.

86 Ibid., 67-9.

87 Ibid., 74 .

${ }^{88}$ Ibid., 76 and 103-5.

89 Roberto Ago, 'Positive Law and International Law', 51 AJIL (1957), 691, 729.

${ }^{90}$ Ago (n. 83), 78-9.

91 Ibid., 79 and $82-3$. 
legitimate if this is intended as the "seat" of the norms (a sort of real substratum, 'the place where they are born, live and $\mathrm{die}^{392}$ ), and not their source as, according to Ago, was Giuliano's intention. ${ }^{93}$ All general international law is customary and customary law is always a law of spontaneous formation, whose ascertainment requires inductive analysis. Treaty law is always positive law, and the establishment of its obligatory nature is the object of deductive analysis. ${ }^{94}$ Those which are normally considered constitutive elements of custom (opinio iuris sive necessitatis and diuturnitas) are in reality nothing more than proof, distinctive signs of its existence. The error always lies in the positivist idea, revised and corrected by normative and dogmatic orientations, according to which the law (including custom) is the product of normative procedures. ${ }^{95}$ However, the construction of a normative hierarchy remains among the essential tasks that legal science must carry out whenever it proposes to attain systematic knowledge of a legal order. ${ }^{96}$ In constructing this hierarchy, one must place the norms of spontaneous formation at the top. Below them sit the norms posited by normative facts envisaged as sources by spontaneous norms, namely treaties. And finally, at the bottom of the hierarchy, are the rules produced by "third degree" sources. Furthermore, in order to move further away from the theory of the basic norm, Ago states that spontaneous norms are multiple and not reducible to a single norm of legal production. ${ }^{97}$

Ago's theory-which (with a few minor changes) Sereni ${ }^{98}$ believed would supersede Giuliano's original construction-also met with lively criticism. In addition to the previously mentioned accusations of neo-naturalism, neo-imperativism, and neo-normativism (the problem was not so much the "neo-", but rather the combination of all these things), Ago was reproached for proposing 'brutal realism, ${ }^{99}$ since his conception of law would identify itself in a fait accompli. ${ }^{100}$ Moreover, it has been observed that a norm cannot be established in the psyche of the associates without being the product thereof. ${ }^{101}$ It has also been pointed out that in Ago's theory legal science ultimately becomes the source of law, a role that it

$92 \operatorname{Ago}($ n. 89), 726, footnote 102.

93 Ibid., 727 ('It is not enough, after having proved that a definition of law as the will of the state or as all the laws created by the state, is wrong, simply to substitute for state a society more or less artificially personified').

94 Ago (n. 83), 107-8.

95 In this regard, Ago (n. 83), 87, footnote 1, shares Bobbio's and Quadri's thesis. See Norberto Bobbio, La consuetudine come fatto normativo (Padova: Cedam 1942) 53 and Quadri (n. 39), 130, according to which opinio juris cannot be a constitutive element of custom as it is the result of an error (that of considering legally obligatory what is not yet obligatory). On the other hand, Ago (n. 83) also believes that it is not possible to completely get rid of opinio, because otherwise it would not be possible to distinguish between the cases in which certain traditional uses create law and those in which this does not happen.

${ }^{96}$ Ago (n. 83), 96-7.

97 Ibid., 98.

98 Sereni (n. 81), 285-9.

99 Quadri (n. 39), 29.

100 In this sense, see Sereni (n. 81), 288; Kunz (n. 76), 90-1.

101 Quadri (n. 39), 33. 
cannot have, ${ }^{102}$ and that-since Ago's theory presents itself as a general theory-if it were true that customary law is not positive, then 'the United Kingdom would have no positive constitutional law and even the "positive" i.e., enacted, law would have its "raison d'etre" in non-positive, i.e., "spontaneous law". Do common law countries have no positive law?'103 Finally, the "conscience" of the members of the international community has been defined as being none other than the traditional element of opinio iuris necessary for the formation of customary law. ${ }^{104}$

\section{6. (Sequitur): The Detection and Integration of General "Spontaneous" Law in Barile.}

Giuseppe Barile (1919-89, full professor in Perugia, Catania, Florence, and Rome) certainly belongs to the current of spontaneous law, ${ }^{105}$ his main contribution in this area being to investigate the creative role of the judge in the discovery of general international law. His starting point is very much influenced by Ago's theory: positive law created by will and spontaneous law have different identifying characteristics. ${ }^{106}$ Positive law is either a command of an organization or a norm formulated by the parties to an agreement. Its interpretation must adapt to the will that created it. The dogmatic method still plays a central role with regard to ius volontarium. ${ }^{107}$

On the other hand, spontaneous law (jus non scriptum) is neither a command nor an agreement, but resides in the conscience of the members of the community in which it operates. It is therefore not the fruit of a heteronymous act of will, but the effect of an act of knowledge and conscience of the interpreter (i.e. the judge). ${ }^{108}$ The interpreter must immediately "read" the conscience of the members of the international community and formulate, on the basis of historical facts, a rule that constitutes an objective norm (historical facts being only means of proof of the existence thereof) ${ }^{109}$. This is a mixed operation, involving both an element of detection and an element of integration. Both phases involve a creative role for the judge. Through detection, the judge must bring the conscious and objective legal sense of an average member of the international community to life in his conscience, through the experience of historical facts. ${ }^{110}$ In using this historical

$102 \operatorname{Kunz}($ n. 76), 90.

103 Ibid., 89.

104 Focarelli (n. 11), 471.

105 For his explicit adhesion, see Giuseppe Barile, I diritti assoluti nellordinamento internazionale (Milano: Giuffrè 1951), 71, footnote 21.

106 Giuseppe Barile, 'Diritto internazionale e diritto interno', 39 RDI (1956), 449, 457.

107 Ibid., 458.

108 Ibid., 459-60.

109 Giuseppe Barile, 'La rilevazione e l'integrazione del diritto internazionale non scritto e la libertà di apprezzamento del giudice', 5 Comunicazioni e studi (1957), 141, 159.

110 Ibid., 163. 
method the judge can avail himself of a wide freedom of appreciation, since he must relate his representation of the collective legal conscience to the present. ${ }^{111} \mathrm{In}$ other words it is the judge who, although with effects limited to the specific case, adds the last conscious contribution to the procedure of formation of the general norm ${ }^{112}$ (an idea shared by Bentivoglio, according to whom this implies that judicial evaluation constitutes the final moment of externalization of norms already existing in the juridical-social reality). ${ }^{113}$

The second operation entrusted to the judge in the case of unwritten rules is their integration. In fact, most unwritten international norms indicate only an end to be achieved. They must therefore be supplemented by other rules which have an instrumental function. ${ }^{114}$ However, such instrumental rules are rarely provided for by international law. To achieve the goals indicated by the rules, it is then necessary for the judge, although authorized to decide only on the basis of law, to integrate the unwritten norms by formulating the instrumental rules necessary for the solution of the case. Among the principles that require the judge to perform an integrative function, Barile cites: the pacta sunt servanda rule; the principle that requires respect for the personal and property assets of foreign citizens; the rule establishing the equivalence between damage and reparation; the norm on international condominia; and the principle of good administration of international justice (in this regard, the freedom of discretion of the judge would have been recognized by the Permanent Court of International Justice in the Mavrommatis affair). ${ }^{115}$ Each of these principles is reconstructed on the basis of a careful analysis of international practice, which shows that the abstractionism the Italian doctrine was accused of in the immediate post-war period was starting to dissipate. Barile's theory-in particular the creative role attributed to the judge-has however been accused of normative subjectivism, an aspect which runs contrary to the objective nature that should characterize legal norms. The discretionary role of the judge would,in fact, create a situation of legal uncertainty, aggravated by the difficulty of capturing the psychological sentiment of a "mythical" average member of the international community. ${ }^{116}$

111 Ibid., 168.

112 Ibid., 169.

113 Bentivoglio (n. 80), 29.

114 Barile (n. 109), $191 \mathrm{ff}$.

115 Ibid., 211 (the passage quoted is the following: 'The Court therefore is at liberty to adopt the principle which it considers best calculated to ensure the administration of justice, most suited to procedure before an international tribunal and most in conformity with the fundamental principles of international law', PCIJ, The Mavrommatis Palestine Concessions, 1924, Publications of the Permanent Court of International Justice, Series A, n. 2, 16).

116 See Sereni (n. 81), 290-1. 


\section{The Social Basis of International Law: The State as a "Real" Person}

The theory of the State as a given, real (and not legal) person was born in the years around the end of World War II of Quadri and Giuliano and subsequently developed in two monographs (Gli enti soggetti dellordinamento internazionale of 1951 and Sulla dinamica della base sociale nel diritto internazionale of 1954) written by Gaetano Arangio-Ruiz (1919, full professor in several universities including Bologna, Padua, and Rome; in charge of the general course at The Hague Academy in 1984; and special rapporteur at the International Law Commission). As we shall see, this theory is closely linked to the critique of the Kelsenian axiom of the strict division between Sein and Sollen, and consequently of the non-deductibility of law from fact, along with the affirmation of a strict separation between international and inter-individual legal orders (dualism).

The idea that legal personality is not a quality inherent in a factual entity, like the State, but rather a legal qualification attributed to it by a given legal order, is also advocated in the Italian doctrine by Perassi, in a mitigated version. In fact, according to Perassi, it is true that every order determines its own subjects, but the procedure by which an order attributes personality could also be automatic, in the sense that norms address themselves directly to certain entities when they fulfill certain conditions of fact. ${ }^{117}$

Arguing against the postulate of non-deductibility of law from fact, Quadri-in the entry "State" of 1940—criticized Kelsen's thesis ${ }^{118}$ that international law would be completely inconceivable if it did not independently determine (through the principles of effectiveness) what a "State" is. Unlike Kelsen, Quadri believes that there is no need for a legal qualification of the State. This intermediary operation is not necessary to connect factual phenomena to their legal consequences. ${ }^{119} \mathrm{In}$ other words, there is no general rule that qualifies or defines States; law merely indicates some factual requirements and automatically connects legal consequences to those requirements. Quadri also reiterates a clarification already made in a previous work, ${ }^{120}$ namely that in the notion accepted by the general theory, the people and the territory are not constitutive of statehood (as was implied in Jellinek's DreiElemente-Lehre): they only represent the ambit in which the State exercises its activity, and therefore its 'objects of domination.' ${ }^{121}$ A State exists when an entity is able to dominate all the other forces that are part of the society. ${ }^{122}$ The formation

\footnotetext{
117 Perassi (n. 22), 43-5.

118 See Hans Kelsen, Das Problem der Souveränität und die Theorie des Völkerrechts (Tübingen: Mohr 1920), 230 ff. See also Hans Kelsen, General Theory of Law and State (Cambridge, MA: Harvard University Press 1945), 221 ('if international law did not determine what a State is, then its norms would not be applicable').

119 Quadri (n. 52), 84-5.

120 Rolando Quadri, La sudditanza nel diritto internazionale (Padova: Cedam1936), 26 ff.

121 Quadri (n. 52), 98.

122 Ibid., 101.
} 
and extinction of States is therefore a question of fact, not of law. Finally, the State is a person of international law, that is to say, an addressee of general norms (starting with the pacta sunt servanda rule) simply because it factually exists. ${ }^{123}$

As we have already seen, the idea of a direct transition from fact to law (i.e. a transition that does not require a legal qualification of facts through norms) is already advocated by Quadri when he maintains that international law is founded on social reality. The non-existence of a legal reason preventing law from connecting legal consequences to a given fact considered in itself, that is, independently of a legal qualification, is an idea also accepted by Morelli, a normativist. Indeed, also according to Morelli, general norms address themselves immediately and automatically to factually existing States. ${ }^{124}$ The same idea is shared by Giuliano. The latter author overturns Kelsen's reasoning: law does not create social reality. As a matter of fact, exactly the opposite is true: law is a product of that reality. ${ }^{125}$ If legal norms attributing international personality or determining the requisites for its acquisition existed, they would be without addressees. ${ }^{126}$ The first rule regarding international personality, in fact, would be limited to establishing who the addressees of the other rules of the legal system are. If, on the other hand, the first norm had its own addressees, then this rule would be completely superfluous, because it would attribute a quality that its addressees already have. Therefore Kelsen's idea of a norm that attributes personality, that is to say designates the addressees of the other norms, is either a petitio principii or a logical absurdity. ${ }^{127}$

The fundamental works of Arangio-Ruiz fit into this doctrinal picture, even if their premise should rather be sought in the dogmatic separation between international and domestic legal orders. A statement often repeated by Arangio-Ruiz, in fact, is that there is no universal community of human beings, and therefore there is no universal (inter-individual) public law. ${ }^{128}$ Individuals belong to their respective political communities and are subject to their respective legal orders. The discontinuity between individual human communities and their legal orders creates a legal vacuum, precisely because individuals are not connected by a universal inter-individual order. International law operates in this vacuum. A consequence of this view is that States are persons in a final (or ultimate) sense, and not "intermediate" subjects in function of the individuals (according to the Kelsenian idea of individuals as the final, "mediated" addressees of international rules).

Against this general background, the question examined by Arangio-Ruiz in Gli enti soggetti dell'ordinamento internazionale concerns the constitution of the

123 Ibid., 120-1.

124 Morelli, Nozioni (n. 20), 126-7.

125 Giuliano (n. 58), 239 ff.

126 Ibid., 249.

127 Ibid., 250.

128 Gaetano Arangio-Ruiz, Gli enti soggetti dell’ordinamento internazionale (Milano: Giuffrè 1951), passim; Gaetano Arangio-Ruiz, 'Rapporti contrattuali fra Stati ed organizzazione internazionale (per una teoria dualista delle unioni di Stati)', 8 Archivio giuridico (1950), 7, 55. 
real entities that are the addressees of international norms. The starting point of his analysis is that the State in international law is not a legal person in the sense in which the State is a legal person in domestic law. Instead, it is a real person-a given entity-presupposed by the international legal order as the physical person is presupposed by the internal legal order. In domestic legal systems, law creates legal persons as an artificial center of imputation of subjective legal situations. ${ }^{129}$ International law, on the other hand, is in a passive position with respect to the State, in the sense that it does not participate in its formation, modification, extinction, or organization. The international order considers the State in its historical materiality, exactly as individuals are considered in domestic law. In this regard, the Kelsenian principal of effectiveness (the norm that would "create" the State as an international legal subject), is a pseudo-norm, lacking any real normative content, since it merely reproduces causal-historical reality. ${ }^{130}$ Moreover, the legitimacy of the formation of States would be irrelevant under international law. ${ }^{131}$ The only material criterion that actually matters is their "material" effectiveness.

Another point developed with great clarity, particularly in the monograph Sulla dinamica della base sociale, is that the central element that explains the subjectivity not only of States, but also of other entities in international law, is their being "powers" or potentates. This quality exists when an entity is independent, when it is not subordinated to other superior entities within an inter-individual (i.e. internal) order. Subjects are the entities that stand as pares, that is, as autonomous centers of volition or action toward similar entities, and therefore potentates. This counts more than being superordinate to a mass of subjects, which may not exist (as is the case for the Holy See, which is nonetheless regarded as being endowed with international personality). ${ }^{132}$

Obviously, one of the effects produced by the theory of the State as a real person in international law, along with the abandonment of the theory of the collective will, is that of rejecting the thesis of the constitutive effect of recognition (advocated early on by Anzilotti). ${ }^{133}$ The effect of recognition is either to confirm the existence of a situation with obligatory effects for the recognizing actor ${ }^{134}$ or, on the political level, to be a 'founding act of the social international life' (or both). ${ }^{135}$

129 Arangio-Ruiz, Gli enti (n. 128), 59.

130 Ibid., $202 \mathrm{ff}$.

131 Ibid., 178-9.

132 Gaetano Arangio-Ruiz, Sulla dinamica della base sociale nel diritto internazionale (Milano: Giuffrè 1954), 122.

${ }^{133}$ But see Giuseppe Sperduti, 'Il riconoscimento internazionale di Stati e di governi', 38 RDI (1953), 30,55 (who speaks of an 'act of constitutive ascertainment').

${ }^{134}$ Gian Carlo Venturini, Il riconoscimento nel diritto internazionale (Milano: Giuffrè 1946), 56; Barile (n. 74), 451; Morelli, Nozioni (n. 20), 129.

135 See Sperduti (n. 133), 62, and Quadri (n. 39), 451. 


\section{8. (Sequitur): Of International Organizations and Individuals}

The centrality of independence and international organizations' ability to emerge as autonomous centers of volition and action on the level of international relations also drives Arangio-Ruiz to recognize their "primary" international personality. ${ }^{136}$ This is an objective personality, which derives from the general norms whose subjective and objective elements are fulfilled by the activity of such organizations, and not a personality created by the constitutive agreement between Member States. This agreement, indeed, must be considered as a contract, and therefore can only produce obligatory effects between its contracting States. ${ }^{137}$ In fact, given the international community's structural characteristics of a lack of organicity and of organization, there is no general rule that attributes to these agreements the effect of constituting a legal status that must exist erga omnes as legal personality does. The apparatuses of international organizations should be considered as "organs of functions" (a notion coined by Perassi). They put in place normative facts, facts that the norms contained in the founding agreements contemplate as suitable to concretize the abstract obligations imposed on the contracting parties. ${ }^{138}$ In any case, agreements establishing international organizations do not entail a structural change in the international community, because they do not bring about a phenomenon of vertical organization of the international society (i.e. the organization's apparatus does not acquire any real international power that renders it "superior" with respect to the Member States). ${ }^{139}$

The valorization of contractualism in an analysis of the phenomenon of international organizations characterizes a subsequent work concerning, this time, not the legal personality of such organizations, but the function performed by agreements in controlling the legality and reconstructing the effects of the acts adopted by their organs. In La funzione dellaccordo nel sistema delle Nazioni Unite, Benedetto Conforti (1930-2016, full professor in Siena, Rome and Naples, then Judge at the European Court of Human Rights) points out that the will of States often plays a role not foreseen in the UN Charter. On the one hand, in fact, in the absence of ad hoc bodies entrusted with the task of objectively controlling the legality of institutional acts, the only tool to eliminate disputes regarding their legality, on a case-by-case basis, is Member States' acquiescence (a contractualist notion). ${ }^{140}$ For States that continue to challenge the legality of an act, however, the resolution will continue to be res inter alios acta. ${ }^{141}$ By this reasoning, the

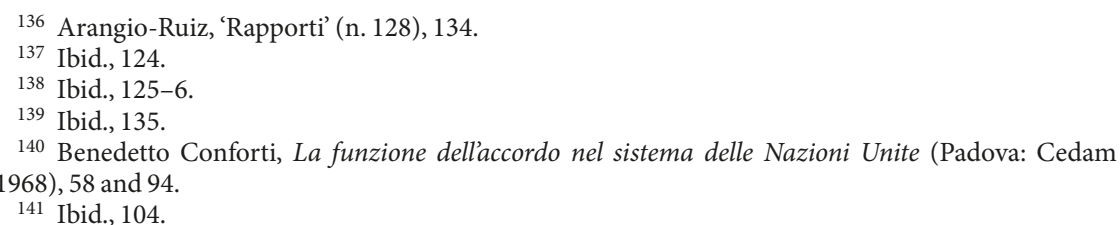


distinction between recommendations and decisions is devalued. ${ }^{142}$ On the other hand, Conforti emphasizes that, in certain cases, the resolutions of UN bodies can produce effects not provided for in the Statute. Indeed, even if these resolutions are in themselves devoid of binding effects (as is often the case), they can produce the same effects as an agreement vis-à-vis the States that, by voting favorably, can be considered to have manifested an effective will to comply with the provisions contained in those acts. ${ }^{143} \mathrm{~A}$ classic example is the declarations of principles adopted by the UN General Assembly, which equate the violation of the principles codified therein with the violation of the UN Charter or general international law. By virtue of this assimilation, States voting in favor of their adoption would, in fact, undertake to respect their content. ${ }^{144}$

To conclude with the (alleged) social basis, the abovementioned discontinuity between legal orders also provides Arangio-Ruiz with an argument to deny the personality of individuals under international law. ${ }^{145}$ This problem has traditionally received a negative response in the Italian scholarship. ${ }^{146}$ Sperduti was of a different opinion, rejecting the idea that individuals could be regarded as mere objects of international norms. He rather posits that they are centers of interests protected by the international order, and therefore neither simple objects nor truly subjects of norms, which continue to be formally addressed to States, but 'material' subjects. ${ }^{147}$ Arangio-Ruiz, on the other hand, examines the three theories asserting the legal personality of individuals in international law (the indirect personality according to general law, linked to the Kelsenian idea that law is always a rule of human conduct and that, therefore, international law also addresses itself to individuals, through the mediation of the State; the direct personality according to general international law connected to delicta juris gentium; and, finally, the direct personality according to conventional law, deriving from the systems of protection of human rights). Eventually, he observes that in all these hypotheses, a fracture always intervenes before the international norm reaches the juridical sphere of individuals with its own effects. This fracture is typical of the relationship between international and domestic law and is induced by the interposition of the volition and action of the "real" person of the State, regarded as the ultimate subject of norms in the international legal order. The individual's legal sphere will be modified only within the inter-individual legal order to which he belongs.

142 Ibid., 117.

143 Ibid., 137.

144 Ibid., 145 ff.

145 Arangio-Ruiz, Gli enti (n. 128), $253 \mathrm{ff}$.

146 Dionisio Anzilotti, Corso di diritto internazionale (4th ed, Padova: Cedam 1955), 121; Morelli, Nozioni (n. 20), 110-18; Quadri (n. 39), 398 ff.

147 Giuseppe Sperduti, L'individuo nel diritto internazionale (Milano: Giuffrè 1950), 106. 


\section{Conclusions}

Some of the notions analyzed in this chapter have become identifying categories of the Italian internationalist doctrine tout court. Spontaneous law, uti universi intervention, potentates, supreme source, the conscience of the international community, and so on are part of a common scientific heritage that surpasses individual scientific or academic orientations. This legacy represents a significant endowement visible in the theoretical trends maintained in subsequent decades by Italian scholars, who have long remained closely connected to the conceptual positions developed in the immediate aftermath of World War II. ${ }^{148}$ In the period examined, as discussed, the two scientific currents inherited from the interwar period (dogmatism and structuralism) are often mixed, interconnected, giving rise to a fruitful eclecticism. The growing trend toward realism (a term that took on different meanings in the Milanese school inaugurated by Ago, Giuliano, and Ziccardi and in the Neapolitan school led by Quadri) appears as one of the most salient facts of the period examined, although strict formalism and (neo-)normativism continued to attract various adherents, for example in the Roman school founded by Perassi and subsequently led by Morelli and Arangio-Ruiz. In this panorama, the Rivista di diritto internazionale (whose publication resumed in 1953) continued to offer an authoritative tribune open to every scientific orientation, even if firmly grounded in the tradition of positivist inquiry.

However, in addition to the results achieved regarding the merits of the topics examined, the post-World War II period coincides with an important evolution concerning method. While the call for empiricism launched early on by positivists was sterilized by the formalism and conceptualism inherited from the fascist period, the late 1950s introduced some novelties that also played a significant role, especially in subsequent periods. First, apart from the highly theoretical studies examined above, several scholars focused their attention on the analysis of new topics, more attuned to the reality of the times, such as the activity of international organizations, which characterizes the passage from the international law of coexistence to the law of cooperation, or early studies on human rights. ${ }^{149}$ The latter element was complemented by timely analysis on certain sensitive topics, including those with a political relevance for Italy, as analyzed elsewhere, ${ }^{150}$ accentuated from the 1960s onward. ${ }^{151}$ Second, an additional characteristic element emerged, namely a different mode of investigation, which was extremely attentive to the analysis of practical data, while still largely encapsulated in theoretical frameworks and able to foster conceptual analysis.

\footnotetext{
148 See for further references Cassese (n. 13) and Cannizzaro (n. 14).

149 See, for an analysis, Pasquale De Sena, 'La dottrina internazionalistica italiana e la tutela internazionale dei diritti dell'uomo (1945-2005)', 6 Diritti umani e diritto internazionale (2012), 513.

150 See Chapter 17 by Enrico Milano.

151 Cassese (n. 13), 125-7.
} 
Ultimately, besides the "iconic" conceptual categories mentioned above, the ability to reconcile theoretical critique, knowledge of the doctrine in several languages, and analysis of practice, constitutes one of the most important legacies offered by the Italian post-World War II doctrine to subsequent generations of scholars.

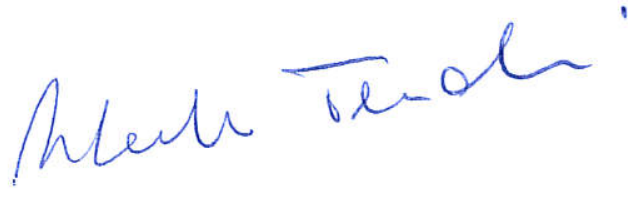

